Journal of Education and Teaching Learning (JETL) 2019

Vol. 1, No. 3, 19-30

Journal Homepage: http://pusdikra-publishing.com/index.php/jetl

\title{
PENERAPAN MODEL PEMBELAJARAN MAKE A MATCH UNTUK MENINGKATKAN KUALITAS PEMBELAJARAN IPS PADA SISWA KELAS VI SDN.106828 SUMBEREJO KECAMATAN PAGAR MERBAU KABUPATEN DELI SERDANG
}

\section{Saktiando Hutabarat*)}

\begin{abstract}
Abstrak
IImu Pengetahuan Sosial adalah bidang studi yang mempelajari, menelaah,menganalisis, gejala dan masalah sosial di masyarakat dengan meninjau dari berbagai aspek kehidupan. Berdasarkan refleksi awal pelaksanaan pembelajaran IPS di kelas VI SDN.106828 Sumberejo Kecamatan Pagar Merbau Kabupaten Deli Serdang menunjukkan bahwa kualitas pembelajaran belum optimal. Hal ini disebabkan adanya beberapa kendala dari guru, siswa dan metode pembelajaran yang digunakan. Kondisi tersebut memerlukan suatu perbaikan pembelajaran yang lebih inovatif dan menarik bagi siswa. Peneliti mengambil solusi untuk melaksanakan PTK menggunakan model Make a Match. Rumusan masalah penelitian ini adalah apakah model Make a Match dapat meningkatkan keterampilan guru, aktivitas siswa dan hasil belajar siswa. Tujuan dari penelitian ini adalah meningkatkan keterampilan guru, aktivitas siswa, dan hasil belajar IPS siswa kelas VI SDN.106828 Sumberejo Kecamatan Pagar Merbau Kabupaten Deli Serdang.Penelitian yang dilakukan merupakan penelitian tindakan kelas dengan tahapan perencanaan, pelaksanaan tindakan, observasi dan refleksi. Penelitian dilakukan sebanyak 2 siklus dengan 2 kali pertemuan setiap siklus. Subjek penelitian ini adalah guru dan siswa kelas VI SDN.106828 Sumberejo Kecamatan Pagar Merbau Kabupaten Deli Serdang.Hasil belajar siswa pada siklus I mencapai presentase ketuntasan klasikal 69,23\%, kemudian meningkat pada siklus II yaitu presentase ketuntasan klasikal mencapai 88.46\%.Berdasarkan hasil penelitian tersebut dapat disimpulkan bahwa model pembelajaran Make a Match dapat meningkatkan hasil belajar siswa kelas VI SDN.106828 Sumberejo Kecamatan Pagar Merbau Kabupaten Deli Serdang.Saran yang diusulkan peneliti adalah guru hendaknya melakukan pembelajaran yang inovatif dan menarik,misalnya dengan menerapkan model pembelajaran Make a Match ketika mengajar. Selain itu siswa harus dilibatkan secara aktif selama proses belajar mengajar berlangsung.
\end{abstract}

Kata kunci: IPS; Kualitas; Pembelajaran; Make A Match.

\section{PENDAHULUAN}

Pendidikan merupakan hal yang sangat penting dalam pembentukan sikap dan kepribadian manusia. Melalui pendidikan, manusia memperoleh ilmu pengetahuan dan pengalaman yang sangat berguna bagi kelangsungan hidupnya.Sebagaimana dijabarkan dalam Undang-undang No 20 tahun 2003 pasal 3 menyebutkan bahwa pendidikan

\footnotetext{
*) Penulis adalah guru SDN.106828 Sumberejo Kecamatan Pagar Merbau Kabupaten Deli Serdang
} 
nasional berfungsi untuk mengembangkan kemampuan dan membentuk watak serta peradaban bangsa yang bermartabat dalam rangka mencerdaskan kehidupan bangsa, bertujuan berkembangnya potensi peserta didik agar menjadi manusia yang beriman dan bertakwa kepada Tuhan Yang Maha Esa, berakhlak mulia, sehat, berilmu, cakap, kreatif, mandiri, dan menjadi warga negara yang demokratis serta bertanggung jawab.

Menurut UU Sisdiknas No. 20 tahun 2003 pasal 4 disebutkan bahwa pendidikan diselenggarakan dengan memberi keteladanan, membangun kemauan,dan mengembangkan kreativitas peserta didik dalam proses pembelajaran.Sesuai dengan undang-undang tersebut,seorang guru diharapkan bisa melakukan kegiatan pembelajaran yang bermanfaat bagi siswa.Di sisi lain, pembelajaran sebisa mungkin dilakukan dengan menarik minat dan kemauan siswa agar timbul motivasi dan keinginan untuk belajar dari dalam diri siswa.

Berdasarkan Undang-undang Nomor 20 tahun 2003 pasal 37 ayat 1 menyebutkan bahwa IImu Pengetahuan Sosial merupakan salah satu mata pelajaran wajib pada kurikulum tingkat dasar dan menengah. IImu Pengetahuan Sosial adalah bidang studi yang mempelajari, menelaah, menganalisis gejala dan masalah sosial di masyarakat dengan meninjau dari berbagai aspek kehidupan.

Berdasarkan Standar Kompetensi dan Kompetensi Dasar Tingkat SD/MI dalam Peraturan Mentri Pendidikan Nasional Nomor 22 Tahun 2006 tentang Standar isi untuk satuan pendidikan dasar dan menengah bahwa standar kompetensi IPS mengkaji seperangkat peristiwa, fakta, konsep, dan generalisasi yang berkaitan dengan isu sosial. Pada jenjang SD/MI mata pelajaran IPS memuat materi Geografi, Sejarah, Sosiologi, dan Ekonomi.

Tujuan mata pelajaran IPS yang telah tertuang dalam KTSP adalah agar peserta didik memiliki kemampuan sebagai berikut: 1) mengenal konsep-konsep yang berkaitan dengan kehidupan masyarakat dan lingkungannya, 2) memiliki kemampuan dasar untuk berfikir logis dan kritis,rasa ingi tahu, inquiri,memecahkan masalah dan keterampilan dalam kehidupan sosial, 3) memiliki komitmen dan kesadaran terhadap nilai-nilai sosial dan kemanusiaan, 4) memiliki kemampuan berkomunikasi, bekerja sama dan berkompetisi dalam masyarakat yang majemuk ditingkat lokal, nasional dan global. 
Adapun ruang lingkup dari mata pelajaran IPS meliputi aspek-aspek sebagai berikut : (1) manusia, tempat dan lingkungan, (2) waktu, berkelanjutan,dan perubahan, (3) sistem sosial dan budaya, (4) pelaku ekonomi dan kesejahteraan. Penelitian ini difokuskan pada Standar Kompetensi (SK) Kenampakan Alam Dan Keadaan Sosial Negara-Negara Tetangga Di Asia Tenggara.

Materi IPS dipahami sebagai materi yang hapalan saja, sehingga tes yang digunakan pun lebih menekankan pada hapalan.Padahal berbagai keterampilan berpikir dalam IPS bisa diuji melalui penilaian yang dibuat oleh guru. Selain itu, aspek sarana pembelajaran untuk mendukung pembelajaran IPS pada umumnya masih sangat minim.Beberapa permasalahan tersebut merupakan permasalahan umum dalam pembelajaran IPS.

Berdasarkan hasil observasi pada saat kegiatan pembelajaran yang dilaksanakan, peneliti mendapatkan data bahwa dalam kegiatan pembelajaran IPS di kelas VI ditemukan permasalahan, yaitu kegiatan pembelajaran yang kurang optimal. Berbagai faktor penyebab baik dari guru, siswa, maupun sarana dan media pembelajaran juga menjadi kendala dalam proses kegiatan belajar mengajar.

Dalam pelaksanaanya guru masih mendominasi kegiatan belajar mengajar didalam kelas, guru kurang variatif dalam menggunakan model pembelajaran, guru juga sering memberikan tugas kepada siswa dan kemudian meninggalkan kelas. Dalam proses pembelajaran pun, guru tidak membentuk kelompok diskusi antar siswa, sehingga interaksi antar siswa dalam bertukar pendapat masih sangat kurang.Siswa kurang dituntut untuk berpikir kritis dan luas dalam menanggapi masalah yang dikemukakan guru.Sehingga siswa memiliki minat dan motivasi belajar yang bisa dikatakan rendah, siswa cenderung pasif dalam kegiatan pembelajaran, siswa kurang percaya diri dalam bertanya, menjawab pertanyaan, dan menyampaikan pendapatnya.

Hal-hal tersebut diatas berdampak pada kurangnya kemampuan siswa dalam memahami konsep mata pelajaran IPS. Hal ini dapat dilihat dari data hasil tes awal siswa yang menunjukkan bahwa sebagian besar siswa belum mencapai nilai Kriteria Ketuntasan Minimal (KKM) yang ditetapkan sekolah.Apabila hal ini dibiarkan berlarut-larut maka siswa akan mengalami kesulitan di dalam menerima materi selanjutnya.Pemecahan masalah mata pelajaran IPS pada siswa kelas VI SDN.106828 Sumberejo Kecamatan Pagar 
Merbau Kabupaten Deli Serdang adalah peneliti berdiskusi dengan kolaborator untuk memperbaiki kualitas pembelajaran IPS S.K : Kenampakan Alam Dan Keadaan Sosial Negara-Negara Tetangga Di Asia Tenggara dengan menerapkan model pembelajaran Make a Match.

Dalam model pembelajaran ini, siswa dilibatkan secara langsung untuk menemukan pasangan berdasarkan kartu pertanyaan dan kartu jawaban yang diberikan. Jadi siswa bergerak menemukan dan mencocokan sendiri jawaban yang tepat dari kartu pertanyaaan yang diberikan. Dengan proses pembelajaran yang disisipi dengan permainan ini diharapkan siswa menjadi lebih tertarik dan dapat meningkatkan pemahamannya terhadap materi yang diajarkan.

Berdasarkan uraian di atas, maka peneliti melakukan Penelitian Tindakan Kelas (PTK) dengan judul: "Penerapan Model Pembelajaran Make a Match untuk Meningkatkan Kualitas Pembelajaran IPS pada Siswa Kelas VI SDN.106828 Sumberejo Kecamatan Pagar Merbau Kabupaten Deli Serdang"

\section{Hakikat Belajar}

Menurut Gagne (dalam Suprijono, 2012:2), belajar merupakan perubahan disposisi atau kemampuan yang dicapai seseorang melalui aktivitas. Perubahan disposisi tersebut bukan diperoleh langsung dari proses pertumbuhan seseorang secara ilmiah. Gagne berkeyakinan bahwa belajar dipengaruhi oleh faktor dari luar diri dan faktor dalam diri dan keduanya saling berinteraksi.Belajar merupakan aktivitas manusia yang sangat vital dan secara terus menerus akan dilakukan selama manusia itu masih hidup, menurut Mustofa (2011:16). Belajar adalah suatu proses usaha yang dilakukan seseorang untuk memperoleh suatu perubahan tingkah laku yang baru secara keseluruhan, sebagai hasil pengalamannya sendiri dalam interaksi dengan lingkungannya.(Slameto,2010:2) Sedangkan menurut Rifa'i dan Anni (2011:82), belajar merupakan proses penting bagi perubahan perilaku setiap orang dan belajar itu mencakup segala sesuatu yang dipikirkan dan dikerjakan oleh seseorang. Belajar memiliki peranan penting dalam perkembangan, kebiasaan, sikap, keyakinan, tujuan, kepribadian dan bahkan persepsi seseorang.

Berdasarkan beberapa pendapat di atas dapat ditarik kesimpulan bahwa belajar adalah usaha yang dilakukan individu secara terus-menerus untuk melakukan perubahan 
tingkah laku menuju kearah yang lebih baik yang diperoleh dari pengalamannya dengan diri sendiri dan interaksinya dengan lingkungan di sekitarnya selama individu tersebut masih hidup.

\section{Hakekat Pembelajaran}

Hakekat pembelajaran menurut Arihi (2012:1) pembelajaran berarti proses,cara, perbuatan mempelajari orang atau makhluk hidup belajar.Pembelajaran adalah suatu proses atau upaya menciptakan kondisi belajar dalam mengembangkan kemampuan minat dan bakat siswa secara optimal, sehingga kompetensi dan tujuan pembelajaran dapat tercapai.Pembelajaran merupakan suatu proses terjadinya interaksi belajar dan mengajar dalam suatu kondisi tertentu yang melibatkan beberapa unsur, baik unsur ekstrinsik maupun intrinsik yang melekat pada diri siswa dan guru termasuk lingkungan. Penjelasan ini sejalan dengan undang-undang No. 20 tahun 2003 tentang Sistem Pendidikan Nasional yang menyebutkan bahwa pembelajaran adalah proses interaksi peserta didik dengan pendidik dan sumber belajar pada suatu lingkungan belajar.

Sedangkan menurut Wenger (dalam Huda, 2013:2) pembelajaran bukanlah aktivitas, sesuatu yang dilakukan oleh seseorang ketika ia tidak melakukan aktivitas yang lain. Pembelajaran juga bukanlah sesuatu yang berhenti dilakukan oleh seseorang. Lebih dari itu, pembelajaran bisa terjadi dimana saja dan pada level yang berbeda-beda, secara individual, kolektif, ataupun sosial.Menurut Briggs (dalam Rifa'i dan Anni, 2011:191) bahwa pembelajaran adalah seperangkat peristiwa (events) yang mempengaruhi peserta didik sedemikian rupa sehingga peserta didik itu memperoleh kemudahan.

Berdasarkan beberapa pendapat para ahli di atas, dapat disimpulkan bahwa pembelajaran adalah suatu proses atau cara yang dilakukan oleh pendidik kepada peserta didik untuk memperoleh kemudahan dalam mempelajari apa yang belum mereka ketahui. Proses pembelajaran ini bisa terjadi dimana saja dan dalam kondisi tertentu yang melibatkan berbagai unsur, baik unsur ekstrinsik maupun intrinsik yang melekat pada diri siswa dan guru termasuk lingkungan belajarnya.

\section{Hasil Belajar}


Menurut Rifa'l dan Anni (2011: 85), hasil belajar merupakan perubahan perilaku yang diperoleh peserta didik setelah mengalami kegiatan belajar.Sudjana (2011: 2) menyatakan bahwa hasil belajar merupakan hasil yang diperlihatkan setelah siswa menempuh pengalaman belajarnya (proses belajar mengajar). Proses adalah kegiatan yang dilakukan siswa dalam mencapai tujuan pembelajaran, sedangkan hasil belajar adalah kemampuan-kemampuan yang dimiliki siswa setelah ia menerima pengalaman belajarnya. Sedangkan hasil belajar menurut Poerwanti (2008: 7-4) adalah keberhasilan siswa setelah mengikuti satuan pembelajaran tertentu.

Jadi hasil belajar merupakan tindakan yang diperoleh setelah melakukan proses belajar yaitu dapat berupa tambahnya pengetahuan dan perubahan tingkah laku.

\section{Hakikat IPS}

IImu pengetahuan sosial atau IPS adalah ilmu sosial yang membahas hubungan antara manusia dengan lingkungannya. Lingkungan masyarakat dimana anak didik tumbuh dan berkembang sebagai bagian dari masyarakat,dihadapkan pada berbagai permasalahan yang ada dan terjadi dilingkungan sekitarnya (Solihatin dan Raharjo, 2012:14-15).

Menurut Gunawan (2013:17) hakikat IPS adalah telaah tentang manusia dan dunianya. Manusia sebagai makhluk sosial selalu hidup bersama dengan sesamanya. Dengan kemajuan teknologi pula sekarang ini orang dapat berkomunikasi dengan cepat dimanapun mereka berada melalui handphone dan internet. Kemajuan iptek menyebabkan cepatnya komunikasi antar orang satu dengan lainnya, antara negara satu dengan negara lainnya. Ini berarti arus komunikasi akan semakin cepat pula mengalirnya. Dengan demikian diyakini bahwa orang yang menguasai informasi itulah yang menguasai dunia.

Adapun ruang lingkup dari mata pelajaran IPS meliputi aspek-aspek sebagai berikut : (1) manusia, tempat dan lingkungan, (2) waktu, berkelanjutan, dan perubahan, (3) sistem sosial dan budaya, (4) pelaku ekonomi dan kesejahteraan.Tujuan mata pelajaran IPS yang telah tertuang dalam KTSP adalah agar peserta didik memiliki kemampuan sebagai berikut: 1) mengenal konsep-konsep yang berkaitan dengan kehidupan masyarakat dan lingkungannya, 2) memiliki kemampuan dasar untuk berfikir logis dan kritis,rasa ingi tahu, inquiri,memecahkan masalah dan keterampilan dalam kehidupan 
sosial, 3) memiliki komitmen dan kesadaran terhadap nilai-nilai sosial dan kemanusiaan, 4) memiliki kemampuan berkomunikasi,bekerja sama dan berkompetisi dalam masyarakat yang majemuk ditingkat lokal, nasional dan global.

Sejalan dengan tujuan tersebut, tujuan pendidikan IPS menurut Sumaatmaja 2006 (dalam Gunawan, 2013:16) adalah “ membina anak didik menjadi warga negara yang baik, yang memiliki pengetahuan, dan kepedulian sosial yang berguna bagi dirinya serta bagi masyarakat dan negara" sedangkan secara rinci Hamalik merumuskan tujuan pendidikan IPS berorientasi pada tingkah laku siswa, yaitu:

1. pengetahuan dan pemahaman,

2. sikap hidup belajar

3. nilai-nilai sosial dan sikap,

4. keterampilan

Berdasarkan uraian di atas, maka dapat ditarik kesimpulan bahwa IPS adalah ilmu sosial yang mempelajari interaksi antara manusia dengan lingkungannya serta komunikasinya dengan makhluk-makhluk di sekitarnya.Penelitian ini difokuskan pada ruang lingkup IPS yang membahas tentang manusia, tempat dan lingkungan yaitu mengenai jenis-jenis pekerjaan yang ada disekitar lingkungan manusia.

\section{Pembelajaran Kooperatif Model Make a Match}

\section{Pengertian Pembelajaran Kooperatif}

Menurut Suprijono, (2012:54) pembelajaran kooperatif adalah salah satu pembelajaran berbasis sosial. Pembelajaran kooperatif meliputi semua kerja kelompok termasuk bentuk yang lebih dipimpin oleh guru atau diarahkan oleh guru.Sedangkan menurut Hamdani (2011:30) Pembelajaran kooperatif adalah pembelajaran yang mengimplementasikan model-model pembelajaran inovatif.Dalam pembelajaran kooperatif diterapkan strategi belajar dengan sejumlah siswa sebagai anggota kelompok kecil yang tingkat kemampuannya berbeda.

Model pembelajaran adalah rangkaian kegiatan belajar siswa dalam kelompok tertentu untuk mencapai tujuan pembelajaran yang dirumuskan.Siswa belajar bersama dalam kelompok-kelompok kecil yang saling membantu satu sama lain. Kelas disusun dalam kelompok yang terdiri atas empat atau enam orang siswa, dengan komampuan 
heterogen. Maksud kelompok heterogen adalah terdiri atas campuran kemampuan siswa, jenis kelamin, dan suku. Hal ini bermanfaaat untuk melatih siswa menerima perbedaan cara bekerja dengan teman yang berbeda latar belakangnya.

Berdasarkan uraian di atas, dapat disimpulkan bahwa pembelajaran kooperatif adalah pembelajaran yang dilaksanakan dengan menerapkan model-model pembelajaran yang inovatif melalui kerja kelompok untuk menyelesaikan tugas secara terstruktur dengan teknik kerjasama dan tanggungjawab. Dari definisi mengenai pengertian pembelajaran kooperatif di atas, sesuai dengan akar

penyebab masalah yang ada peneliti memilih salah satu model pembelajaran kooperatif tipe Make a Match untuk meningkatkan kualitas pembelajaran IPS pada siswa kelas VI-B SDN.101878 Tanjung Morawa Kecamatan Tanjung Morawa Kabupaten Deli Serdang.

\section{Model Pembelajaran Kooperatif Make a Match}

Model pembelajaran Make a Match atau mencari pasangan pertama kali dikembangkan oleh Lorna Curran 1994 (dalam Huda, 2013: 251). Salah satu keunggulan teknik ini adalah siswa mencari pasangan sambil belajar mengenai suatu konsep atau topik dalam suasana yang menyenangkan.Model pembelajaran tipe Make a Match dapat dikatakan sebagai model pembelajaran konsep karena model pembelajaran ini mengajak murid mencari jawaban terhadap suatu pertanyaan konsep melalui suatu permainan kartu pasangan.

Penerapan metode ini dimulai dari teknik yaitu siswa disuruh mencari pasangan kartu yang merupakan jawaban/soal sebelum batas waktunya, siswa yang dapat mencocokkan kartunya diberi poin.

Langkah langkah Model Pembelajaran Make A Match menurut Huda (2013:252-253) sebagai berikut:

1. guru menyampaikan materi atau memberi tugas kepada siswa untuk mempelajari materi dirumah.

2. siswa di kelompokkan kedalam dua kelompok, misalnya kelompok $A$ dan kelompok B. Kedua kelompok diminta untuk berhadap-hadapan.

3. guru membagikan kartu pertanyaan kepada kelompok $A$ dan kartu jawaban kepada kelompok B 
4. guru menyampaikan kepada siswa bahwa mereka harus mencari/mencocokan kartu yang dipegang dengan kartu kelompok lain. Guru juga perlu menyampaikan batasan maksimun waktu yang ia berikan kepada mereka.

5. guru meminta semua anggota kelompok $A$ untuk mencari pasangannya di kelompok B. Jika mereka sudah menemukan pasangannya masing-masing,guru meminta mereka melaporkan diri kepadanya. Guru mencatat mereka pada kertas yang sudah dipersiapkan.

6. jika waktu sudah habis, mereka harus diberitahu bahwa waktu sudah habis.Siswa yang belum menemukan pasangan diminta untuk berkumpul tersendiri

7. guru memanggil satu pasangan untuk presentasi. Pasangan lain dan siswa yang tidak mendapat pasangan memperhatikan dan memberi tanggapan apakah pasangan itu cocok atau tidak.

8. terakhir, guru memberikan konfirmasi tentang kebenaran dan kococokan pertanyaan dan jawaban dari pasangan yang memberikan presentasi.

9. guru memanggil pasangan berikutnya, begitu seterusnya sampai seluruh pasangan melakukan presentasi.

\section{METODE PENELITIAN}

Penelitian ini menggunakan jenis Penelitian Tindakan Kelas (PTK).Menurut Aqib, dkk (2014: 3) PTK adalah penelitian yang dilakukan oleh guru di kelasnya sendiri melalui refleksi diri dengan tujuan untuk memperbaiki kinerjanya sehingga hasil belajar siswa meningkat. Menurut Arikunto (2014:58) PTK adalah penelitian tindakan yang dilakukan dengan tujuan memperbaiki mutu praktik pembelajaran di kelasnya.

Pelaksanaan penelitian tindakan kelas menurut Arikunto (2014:16-19) meliputi empat tahap yaitu perencanaan, pelaksanaan, observasi, dan refleksi.

Subjek penelitian ini adalah guru dan siswa kelas VI SDN.106828 Sumberejo Kecamatan Pagar Merbau Kabupaten Deli Serdang.Jumlah siswa yang diteliti adalah 26 siswa terdiri dari 15 siswa perempuan dan 11 siswa laki-laki.

Penelitian ini dilaksanakan di SDN.106828 Sumberejo Kecamatan Pagar Merbau Kabupaten Deli Serdang.

Variabel penelitian ini adalah: 
a. keterampilan guru dalam pembelajaran IPS dengan menerapkan model pembelajaran kooperetif Make a Match.

b. aktivitas siswa dalam pembelajaran IPS dengan menerapkan model pembelajaran kooperetif Make a Match.

c. hasil belajar siswa dalam pembelajaran IPS dengan menerapkan model pembelajaran kooperetif Make a Match.

\section{HASIL DAN PEMBAHASAN PENELITIAN}

\section{A. Data Hasil Penelitian Pada Siklus I danll}

Setelah proses belajar mengajar berlangsung dengan menggunakan metode pembelajaran Make a Match, dilakukan test pada setiap siswa subjek belajar untuk setiap siklus dan diperoleh hasil test setiap siswa. Nilai hasil belajar siswa dapat dilihat pada tabel berikut ini.

Tabel : 4.1 Hasil Test Siklus I

\begin{tabular}{|c|c|c|c|c|}
\hline No & Hasil Tes & Keterangan & Jumlah Siswa & Persentase \\
\hline 1 & Skor $<70$ & Tidak Tuntas & 8 & $30,76 \%$ \\
\hline 2 & Skor $>70$ & Tuntas & 18 & $69,23 \%$ \\
\hline
\end{tabular}

Berdasarkan tabel 4.1.menunjukkan bahwa nilai rata-rata siswa adalah 64,30.Perolehan nilai pada siklus I belum sesuai dengan yang diharapkan karena belum mencapai ketuntasan belajar yaitu pembelajaran dikatakan tuntas bila telah mencapai 75 $\%$ jumlah siswa telah mencapai nilai $\geq 70$.

\section{B. Refleksi}

Setelah melihat hasil analisis data hasil belajar siswa pada siklus I dan pengamatan selama proses pembelajaran berlangsung serta melihat aktivitas siswa, maka perlu dilaksanakan pembelajaran pada siklus II dengan melakukan perbaikan desain, cara mengajar, menyampaikan materi. Perolehan nilai pada siklus I belum sesuai dengan yang diharapkan karena belum mencapai ketuntasan belajar, sehingga penelitian tindakan kelas dilanjutkan pada siklus II dimana pembelajaran tetap menggunakan model pembelajaran Make a Match. 


\section{Data Hasil Penelitian Pada Siklus II}

Tabel 4.2. Hasil Test (Siklus II)

\begin{tabular}{|c|c|c|c|c|}
\hline No & Hasil Tes & Keterangan & Jumlah Siswa & Persentase \\
\hline 1 & Skor $<70$ & Tidak Tuntas & 3 & $11,53 \%$ \\
\hline 2 & Skor $>70$ & Tuntas & 23 & $88,46 \%$ \\
\hline
\end{tabular}

Berdasarkan tabel 4.2.Menunjukkan bahwa nilai rata-rata siswa adalah 86,76.Perolehan nilai pada siklus II sudah sesuai dengan yang diharapkan karena telah mencapai $75 \%$ jumlah siswa telah mencapai $\geq 70$, sehingga penelitian tindakan kelas pada siklus II dimana pembelajaran menggunkan metode pembelajaran Make a Match telah dapat mencapai KKM.

Dari tabel di atas bahwa menggunakan metode pembelajaran Make a Match dapat meningkatkan hasil belajar siswa,dengan demikian berarti tepat bila digunakan model pembelajaran Make a Match pada Materi Kenampakan Alam dan Keadaan Sosial Negaranegara Tetangga pada siswa kelas VI SDN.106828 Sumberejo Kecamatan Pagar Merbau Kabupaten Deli Serdang.

\section{SIMPULAN}

Berdasarkan hasil penelitian dan pembahasan, secara umum dapat disimpulkan bahwa:

1. Dalam proses pembelajaran terjadi peningkatan kualitas pembelajaran IPS di kelas VI SDN.106828 Sumberejo Kecamatan Pagar Merbau Kabupaten Deli Serdang,dengan menerapkan model Make a Match.

2. Terjadi peningkatan keterampilan guru dan aktivitas siswa dalam proses pembelajaran IPS dengan menerapkan model Make a Match

3. Terjadi peningkatan hasil belajar siswa dalam pembelajaran IPS yang telah memenuhi Kriteria Ketuntasan Minimal yang telah ditetapkan.

\section{DAFTAR PUSTAKA}

Anitah, Sri dkk. 2011. Strategi Pembelajaran SD. Jakarta: Universitas Terbuka. 
Arikunto, Suharsimi dkk. 2006. Prosedur Penilaian Suatu Pendekatan Praktik. Jakarta: Rineka Cipta.

Arikunto, Suharsimi dkk. 2014. Penelitian Tindakan Kelas. Jakarta: PT Bumi Aksara.

Arsyad, Azhar. 2014. Media Pembelajaran. Jakarta: PT.Rajagrafindo Persada.

Djamarah, Syaiful Bahri dan Aswan Zain. 2013. Strategi Belajar Mengajar. Jakarta: PT Rineka Cipta.

Hamalik, Oemar. 2012. Proses Belajar Mengajar. Jakarta: Bumi Aksara

Majid, Abdul. 2013. Strategi Pembelajaran. Bandumg: PT Remaja Rosdakarya.

Mulyasa. 2009. Kurikulum Tingkat Satuan Pendidikan. Bandung: PT Remaja Rosdakarya Offset.

Rusman. 2014. Model-model Pembelajaran. Bandung: Rajagrafindo Persada.

Slameto. 2010. Belajar \& FaktorOfaktor yang Mempengaruhinya.Jakarta: Rineka Cipta

Thobroni dan Arif Mustofa. 2011. Belajar dan Pembelajaran.Jogjakarta:Ar-ruzz Media

Usman, Uzer. 2013. Menjadi guru Profesional. Bandung : Remaja Rosdakarya.

Zaini, M. F. (2019). The Implementation Of Learning Management In Class VIII Madrasa Tsanawiyah Islamiyah (Mts) Ypi Batangkuis. International Conference on Islamic Educational Management (ICIEM). 